\title{
MTDH wt Allele
}

National Cancer Institute

\section{Source}

National Cancer Institute. MTDH wt Allele. NCI Thesaurus. Code C92659.

Human MTDH wild-type allele is located in the vicinity of $8 \mathrm{q} 22.1$ and is approximately 86 $\mathrm{kb}$ in length. This allele, which encodes protein LYRIC, plays a role in transcriptional regulation, promotion of tumor cell anchorage-independent growth and metastasis. Aberrant expression is associated with prostate cancer and hepatocellular carcinomas. Genetic variation may be associated with migraine. 